\title{
DAMPAK INTERVENSI AKTOR-AKTOR EKSTERNAL DALAM MEMPENGARUHI DURASI PERANG SIPIL DI SURIAH
}

\author{
Muhammad Rizky Nur Kamrullah \& Aspin Nur Arifin Rivai \\ Universitas Indonesia \& Universitas Islam Negeri Alauddin \\ r.nurkamrullah@gmail.com \& askaspin@gmail.com
}

\begin{abstract}
This research aims to further explore the civil war that is taking place in Syria. This paper questions fundamentally, why did the civil war in Syria become a prolonged armed conflict? Or are there other factors that strengthen the strength of their resistance? This research offers a novelty of research on the situation of this conflict, is that the prolonged civil war in Syria is not only caused by internal conditions, but also the involvement of external actors. As with the approach of David E. Cunningham (2010) that the involvement of external actors in civil war produces two possibilities, namely; become a negotiating facilitator and help one party win. This research reveals that the involvement of external actors interventions - regional, international and transnational - actually prolongs the conflict. This is because the involvement of external actors causes the addition of combatants in the conflict, so the preference in the conflict increases.
\end{abstract}

Keywords: Civil War, Assad Regime, Regional Actor, International Actor, and Transnational Actor.

\section{PENDAHULUAN}

Pada masa kontemporer saat ini, perang sipil telah menjadi salah satu ragam konflik yang memberi pengaruh penting dalam dinamika keamanan internasional. Pasalnya, perang sipil tidak sekedar diklasifikasikan sebagai konflik kepentingan antara aktor domestik di dalam satu negara, melainkan memiliki kecendrungan untuk diintervensi oleh kepentingan-kepentingan eksternal (Gleditsch, 2007). Hal ini dapat kita simak secara sistematis mengenai konflik yang berlangsung di Suriah, di mana konflik domestik menjadi persoalan penting bagi berbagai negara yang memiliki hubungan dan kepentingan langsung dan tidak langsung.

Pada dasarnya konflik bersenjata di Suriah dilatarbelakangi oleh kekecewaan bertahun-tahun masyarakat dalam menyikapi rezim Assad. Resistensi ini berawal dari dualitas kelompok yakni Islam Sunni dengan kelompok Alawite dan minoritas lainnya (Kristen, Druze, Yahudi, dll). Konflik sempat memuncak pada Februari 1982, dan dikenal dengan peristiwa Hama Massacre, di mana tentara Suriah atas perintah Hafiz al Assad mengepung dan menguasai kota Hama dalam rangka meredam perlawanan kelompok Muslim Brotherhood. Kelompok ini hadir untuk memperjuangkan Islam sebagai dasar politik Republik Suriah.

Menurut catatan pemberitaan, peredaman konflik itu menumbalkan korban kematian sekitar 2000 lebih masyarakat sipil (Barmin). Bentuk peredaman yang dilakukan oleh pemerintahan Hafez al Assad melalui tindakan hard-power berupa penangkapan, pengasingan 
dan juga penyiksaan. Tindakan ini diambil menjaga stabilitas domestik dan mempertahankan status quo, sehingga kelompok yang berusaha menekannya akan mendapatkan tindakan keji semacam itu. Rezim ini juga membentuk badan khusus bernama Mukhabarat yang secara ketat mengawasi segala bentuk pergerakan di dalam masyarakat Suriah (The Guardian). Praktek politik semacam ini terus berlanjut sampai pada pemerintahan Bashar al Assad, namun resistensi kelompok yang mengalami penekanan tetap bertahan dan melanjutkan perlawanan.

Gelombang aksi demonstrasi pada tahun 2011 semakin memuncak dengan kehadiran konflik bersenjata. Pada Maret 2011 berbagai protes pro-demokrasi meletus di selatan kota Dara'a setelah insiden penangkapan dan penyiksaan terhadap beberapa pemuda yang menuliskan slogan-slogan penentangan di tembok sekolah mereka (Rodgers, Gritten, Offer, \& Asare). Hal tersebut memicu berbagai protes nasional yang menuntut agar presiden Bashar al Assad mengundurkan diri. Pada April 2011 pemerintah mengambil langkah yang cukup keras untuk mengatasi gelombang protes di seluruh penjuru negeri dengan menurunkan tentara, senjata lapis baja, dan juga polisi-polisi khusus yang bertugas menangkap aktivis di dalam gelombang demonstrasi tersebut. Berbagai gelombang protes yang terjadi ternyata diikuti pula dengan banyaknya tentara Suriah yang membelot dan memihak kelompok pro-demokrasi, dan beberapa ribu di antara mereka membentuk Free Syrian Army (Lister, 2016).

Seketika konflik tersebut berubah menjadi konflik bersenjata yang banyak memakan korban jiwa dan kerusakan infrastruktur yang parah. Kurang lebih 250.000 orang kehilangan nyawanya dan lebih dari 11 juta terpaksa mengungsi, sebagai akbiat dari konflik antara pemerintah, oposisi, dan menyusul pula kelompok-kelompok jihadis, dalam usaha mendapatkan kepentingannya masingmasing (Aljazeera, 2015). Konflik yang dimulai pada tahun 2011 dan masih terus berlanjut hingga sekarang, dan belum menandakan potensi untuk diakhiri.

Dari dasar historis sederhana konflik di atas, setidaknya kita bisa menggarisbawahi bahwa keberlangsungan perang sipil merupakan fenomena pergolakan politik yang begitu kompleks karena berlanjut pada dua masa kepemimpinan Suriah. Eskalasi konflik terus mengalami peningkatan meskipun tindakan perlawanan balik dari pemerintah tidak mampu meredupkan secara utuh resistensi kelompok yang berlawanan dengan status quo. Untuk itu, tulisan ini secara khusus berupaya pertanyaan esensial sebagai berikut, mengapa perang sipil di Suriah menjadi konflik bersenjata yang berkepanjangan? Apakah terdapat faktor lain yang memperkuat kekuatan resisitensi mereka? Guna menjawab pertanyaan di atas, tulisan ini tersusun menjadi dua bagian. Bagian pertama, menguraikan perkembangan kajian mengenai 
perang sipil atau konflik bersenjata. Bagian kedua, menguraikan keterlibatan dan kepentingan aktor eksternal.

\section{KERANGKA ANALISIS}

Perang Sipil: Suatu Tinjauan Literatur

Studi mengenai perang sipil atau konflik bersenjata domestik di negara tertentu merupakan salah satu isu penting di dalam kajian keamanan internasional. Isu ini memunculkan suatu perhatian studi-studi internasional pada permasalahan konflik dan perdamaian. Permasalahan konflik internal memunculkan kecenderungan pada upaya untuk menemukan penyebab konflik internal tersebut dan bagaimana cara serta metode penyelesaian konfliknya.

Tulisan-tulisan mengenai kondisi dinamika politik kenegaraan yang menjadi penyebab konflik internal dan upaya-upaya pihak ketiga dalam mendukung terciptanya perdamaian atas konflik tersebut; mendominasi kajian pada permasalahan ini. Namun, terdapat suatu kekosongan pada dua perhatian utama pada isu ini. Hal ini disebabkan oleh kondisi realitas dari konflik internal di beberapa negara yang ternyata semakin berkepanjangan dan mengalami peningkatan ekskalasi di tengah intervensi serta keterlibatan pihak ketiga atau negara lainnya di dalam dinamika konflik internal tersebut. Oleh karena itu, perang sipil tidak hanya dapat dipandang sebagai permasalahan politik domestik saja.

Beberapa literatur akademik membahas persoalan penyebab-penyebab utama dari terjadinya suatu perang sipil atau konflik politik internal. Regan dan Norton berargumen di dalam penelitiannya bahwa perang sipil cenderung terjadi pada kondisi suatu negara yang memiliki distribusi kesejahteraan ekonomi yang tidak merata, pemerintahan yang represif menyikapi protes dari warganya, dan adanya akses kesempatan terhadap sumber daya yang dapat diekspoitasi di suatu negara (Regan \& Norton, 2005).

Adapula Collier dan Hoffler di dalam salah satu tulisannya berusaha untuk memberikan penjelasan mengenai variabel penentu bagi terjadinya perang sipil. Mereka berargumen bahwa kondisi-kondisi suatu negara tertentu dapat menjadi penyebab utama dari terjadinya perang sipil dibandingkan dengan motivasi dari kelompok-kelompok yang bertikai (Collier, Hoeffler, \& Rohner, 2009). Motivasi yang didasari oleh adanya ketidakpuasan ataupun keserakahan akan kekuatan politik dari aktor-aktor yang bertikai, bukan merupakan variabel utama dalam terjadinya perang sipil di suatu negara. Kondisi negara yang gagal, kesenjangan ekonomi yang tinggi, dan adanya daerah abu-abu di dalam suatu negara merupakan pemicu utama dari perang sipil. 
Tulisan-tulisan tersebut memiliki fokus utama pada karakteristik domestik dari suatu negara dalam mempengaruhi terjadinya suatu perang sipil. Memang suatu upaya pencegahan dan penyelesaian suatu konflik domestik membutuhkan pemahaman akan sebab-sebab dari suatu konflik tersebut terjadi. Namun, upaya penyelesaian konflik pada kenyataannya sulit untuk membuahkan hasil hanya dengan melihat hal tersebut, karena konflik dometik bisa semakin memanjang dan mengalami peningkatan eskalasi dengan sebab-sebab atau alasan yang berbeda dari penyebab konflik itu sendiri. Konflik domestik bisa berkembang menjadi suatu konflik kepentingan dari aktor-aktor luar baik negara maupun non-negara. Kombinasi antara kepentingan politik aktor domestik dan aktor luar, mampu menjadi suatu faktor penting dari semakin memanjangnya perang sipil di suatu negara berikut upaya-upaya penyelesaiannya.

Keterlibatan atau intervensi aktor-aktor eksternal di dalam suatu konflik domestik di negara tertentu, memiliki pengaruh yang cukup signifikan dalam mempengaruhi dinamika konflik yang ada. Dinamika ini dapat berarti pengaruh terhadap karakter konflik maupun pengaruh terhadap potensi penyelesaian konflik yang dalam hal ini dapat berupa; penyelesaian dengan cara kemenangan militer maupun negosiasi. Rafizadeh Majid di dalam tulisannya berargumen bahwa konflik perang sipil di Suriah secara khusus memiliki dimensi yang berbedabeda. Menurutnya karakter dan dinamika konflik yang terjadi di Suriah terbentuk oleh empat macam bentuk pengelompokan dan persaingan politik, baik itu domestik maupun regional dan bahkan internasional (Rafizadeh). Interaksi di dalam empat lapis persaingan kepentingan yang terjadi, menjadi pembentuk dari semakin berkepanjangannya dan semakin menghancurkannya perang sipil di Suriah.

Ada pula David E. Cunningham yang secara lebih jelas melakukan pembahasan terhadap bagaimana intervensi negara eksternal di dalam perang sipil cenderung menghasilkan dua kemungkinan, yaitu; menjadi fasilitatior negosiasi dan membantu salah satu pihak untuk menang (Cunningham, 2010). Argumen utamanya adalah bahwa intervensi negara eksternal di dalam perang sipil cenderung memperpanjang konflik yang ada. Hal ini tidak lain karena negara eksternal tersebut memiliki agenda mandiri dibandingkan dengan agenda-agenda yang dimiliki oleh pihak yang bertikai di dalam konflik domestik atau perang sipil (Cunningham, 2010, p. 116).

Negara-negara eksternal pada umumnya mempunyai sedikit dorongan untuk bernegosiasi dibandingkan dengan aktor internal, karena mereka hanya menanggung biaya kecil dan mereka cenderung untuk mengantisipasi kemungkinan keuntungan yang sedikit dari negosiasi dibandingkan dengan kelompok insurjen domestik. Negara eksternal cenderung mengedepankan 
agendanya bukan semata-mata untuk menolong salah satu pihak yang bertikai atau membantu untuk menyelesaikan konflik. Hal ini membuat keterlibatan negara eksternal tersebut dapat dianggap sebagai penambahan kubu atau pihak di dalam konflik domestik itu sendiri. Konflik akan semakin berkepanjangan di saat kombatan semakin banyak karena mereka memiliki preferensi hasil perang yang berbeda-beda. Durasi perang sipil secara umum ditentukan oleh dua kondisi penting, yaitu; kondisi dimana kemenangan militer akan lebih mudah/sulit untuk diperoleh; dan kondisi dimana negosiasi akan lebih mudah/sulit di capai.

Terdapat beberapa alasan mengapa intervensi oleh aktor eksternal yang memiliki agenda sendiri berpotensi mempepanjang konflik. Pertama; keberadaan kombatan yang memiliki preferensi berbeda-beda dan terpisah, menimbulkan penambahan isu-isu di dalam upaya negosiasi. Kedua; di dalam kondisi konflik yang 'ter-fraksionalisasi', kombatan akan sulit untuk menggunakan hasil akhir peperangan untuk dijadikan ukuran keyakinan mereka dalam memenangkan kepentingannya. Ketiga; semakin banyak pihak yang terlibat, semakin banyak pula insentif yang dibutuhkan pihak-pihak tersebut dan hal ini mempuat persetujuan semakin sulit karena akan semakin banyak pihak yang perlu untuk menyetujuinya. Terakhir; negosiasi cenderung gagal karena adanya pergeseran aliansi diantara pihak yang terlibat di saat berbagai isu yang berebeda di ajukan. Hal ini juga dikarenakan adanya kemungkinan kombatan untuk bisa membuat koalisi yang berbeda di dalam area isu yang berbeda pula (Cunningham, 2010, pp. 117-118).

Tulisan ini akan menggunakan argumen dari Cunningham dalam memahami intervensi aktor eksternal di dalam perang sipil. Secara khusus, tulian ini menjadikan kasus perang sipil di Suriah sebagai salah satu contoh yang mampu menggambarkan dampak dan pengaruh dari intervensi aktor-akor eksternal akan karakter dan dinamika konfliknya. Kenyataan bahwa perang sipil yang berkepanjangan di Suriah telah menjadi arena konflik kepentingan bagi negara-negara lainnya; baik regional maupun internasional; menjadi sarana untuk memberikan bukti bahwa keterlibatan aktor luar yang memiliki kepentingan di dalam konflik domestik akan cenderung meningkatkan eskalasi dan memperpanjang konflik. Pada bagian selanjutnya; tulisan ini akan menjelaskan aktor-aktor eksternal yang terlibat berserta kepentingan mereka di dalam konflik ini. 


\section{PEMBAHASAN}

\section{Keterlibatan dan Kepentingan Aktor Eksternal}

Perang sipil di suriah semakin rumit dan sulit untuk dihentikan. Hal tersebut dipengaruhi oleh berbagai faktor kondisi demografi dan politik domestik yang ada di Suriah. Namun, kondisi politik dan geografis yang strategis, menjadikan konflik di Suriah mengundang keterlibatan pihak-pihak eksternal dengan berbagai kepentingan strategisnya. Konflik ini pun ternyata dapat menggambarkan betapa terdapat persaingan kepentingan dan kekuatan pada level regional dan internasional. Konflik domestik di Suriah tidak lagi dapat dipandang sebagai konflik kepentingan antara kubu pemerintah dan pemberontak saja. Konflik ini memiliki nilai strategis bagi aktor-aktor eksternal, baik itu regional maupun internasional. Pengaruh aktor-aktor tersebut sangat menentukan karakter konflik yang terjadi sampai pada saat ini. Keterlibatan aktor-aktor itu, yakni:

\section{Aktor Regional}

Perang sipil di Suriah memiliki dimensi konflik yang cukup luas dengan keterlibatan negaranegara di kawasan dalam mendukung kelompok domestik tertentu yang terlibat di dalam konflik. Letak geografis dan kondisi sosial-politik di Suriah sejak tahun (dikuasai rezim Assad), telah memiliki nilai strategis bagi negara-negara di sekitar wilayah teritorialnya. Persaingan kekuatan di Suriah memberikan kemungkinan bagi adanya pergeseran peta kekuatan dan pengaruh di Timur Tengah. Persaingan pengaruh politik antara Iran dan Arab Saudi beserta negara-negara arab teluk ikut memengaruhi dan membentuk karakter konflik di Suriah.

Salah satu negara di kawasan Timur Tengah yang memiliki kepentingan dan pengaruh penting di dalam perang sipil di Suriah adalah Iran. Iran menjadi salah satu penyokong kuat rezim Assad di Suriah selama konflik domestik berlangsung. Bahkan banyak yang menyatakan bahwa, tanpa bantuan serta dukungan dari Iran, pemerintahan Bashar al Assad tidak akan dapat bertahan. Dibalik kesamaan dalam latarbelakang keagamaan, kedekatan antara Iran dan pemerintahan Assad lebih kepada alasan-alasan geopolitik. Perang Iran-Irak menjadi persinggungan utama antara Iran dan pemerintahan Assad, dimana Suriah menjadi negara di kawasan Timur Tengah yang mendukung Iran. Namun, hal utama yang menjadi nilai strategis bagi Iran dalam dukungannya terhadap pemerintahan Assad kondisi konflik saat ini adalah kemungkinan jatuhnya Assad dan melahirkan pemerintahan yang pro-Sunni di Suriah (Barfi, 2016).

Hal tersebut memberikan kekhawatiran pada Iran apabila hal tersebut terjadi, pengiriman logistik dan persenjataan ke Hizbullah di Lebanon akan terhambat. Oleh karena itu, Iran terus 
melakukan upaya untuk mempertahankan pemerintahan Suriah saat ini, diantaranya adalah dengan memberikan bantuan intelijen dan pelatihan militer oleh Islamic Revolutionary Guard Corps Iran. Selain itu, Iran juga menyediakan suplai senjata bagi tentara pemerintahan Suriah dari udara. Hizbullah pun ikut terlibat secara signifikan di dalam konflik yang terjadi dan memberikan tambahan kekuatan personel di lapangan (Fulton, Holliday, \& Wyer, 2013).

Aktor regional lainnya yang juga memiliki kepentingan dan pengaruh dalam konflik di Suriah adalah kelompok negara-negara Arab Teluk (Arab Saudi, Kuwait, Qatar, Bahrain, Oman, Uni Emirate Arab). Konflik domestik di Suriah memberikan kemungkinan adanya perubahan karakter politik di Suriah yang selama ini pro-Iran, dan hal tersebut menjadi peluang bagi Arab Saudi dan negara-negara Arab Teluk merubah peta politik regional di kawasan Timur Tengah. Arab Saudi dan Qatar memberikan bantuan dana untuk gaji pasukan pemberontak Suriah yang berusaha menggulingkan pemerintahan Assad (Alsharif, 2012). Arab Saudi juga memberikan beberapa bantuan persenjataan bagi pihak pemberontak, diantaranya adalah senjata misil antitank (TOW missile) buatan Amerika Serikat (Bassam \& Perry, 2015). Selain itu, Arab Saudi dan negara-negara Arab Teluk lainnya juga terus mendorong intervensi internasional serta mendorong Bashar al Assad untuk mundur, karena telah kehilangan kredibilitas dan legitimasi sebagai pemimpin Suriah. Alasan tersebut menjadi nilai utama yang selalu melatarbelakangi dukungan Arab Saudi terhadap pihak pemberontak (Basma \& Strohecker, 2015).

Terdapat pula negara-negara yang dapat dipengaruhi oleh kondisi yang terjadi di Suriah, dan memiliki kemungkinan untuk ikut memberikan pengaruh secara tidak langsung karena negara-negara tersebut memiliki perbatasan langsung dengan Suriah, diantaranya adalah Turki, Lebanon, Jordania, dan Irak. Faktor utama yang kemungkinan dapat membuat negara-negara tersebut ikut terlibat untuk mempengaruhi konflik di Suriah adalah aliran pengungsi yang datang akibat konflik tersebut. Kurang lebih sebanyak 4,5 juta pengungsu Suriah di Turki, Jordania, Lebanon, Irak, dan Mesir. Sebanyak 2,5 juta jiwa berada di Turki; 1,1 juta jiwa berada di Lebanon; 635,324 jiwa berada di Jordania; 245, 022 jiwa berada di Irak, dan 117, 658 jiwa berada di Mesir (Amnesty International, 2016). Gelombang pengungsi merupakan tanggung jawab yang besar dan dapat menjadi ancaman keamanan bagi negara-negara tersebut. Hal-hal tersebut pada akhirnya mendorong beberapa negara tersebut untuk ikut memihak di dalam konflik domestik di Suriah. 


\section{Aktor Internasional}

Selain memiliki nilai strategis bagi negara-negara di kawasan Timur Tengah; Suriah pun memiliki nilai strategis bagi negara-negara kekuatan global seperti Rusia dan Amerika Serikat. Hal ini menyebabkan perang sipil di Suriah juga menjadi ruang benturan diantara negara-negara tersebut dan membuat dimensi konflik di Suriah meluas ke dimensi internasional. Hal ini juga menyebabkan perang sipil di Suriah dapat menjadi pemicu konflik diantara aktor-aktor global dengan berbagai kepentingan politik dan strategisnya.

Kekuatan besar global yang cukup memiliki kepentingan dan berpengaruh di dalam konflik Suriah diantaranya adalah Rusia. Suriah merupakan sekutu Rusia di kawasan Timur Tengah sejak era Uni Soviet. Sejak tahun 1971, pemerintah suriah memberikan pelabuhan Tartus kepada Rusia sebagai pelabuhan yang memberikan suplai bahan bakar dan perbaikan bagi kapal perang Rusia di perairan Mediterania. Meskipun sempat ditutup pada 1991, kemungkinan kejatuhan rezim Assad akan membuat kesempatan Rusia kembali mendapatkan pelayanan dari pelabuhan tersebut menjadi tertutup (Bagdonas, 2012). Selain itu, keterlibatan militer Rusia di Suriah akan meningkatkan kredibilitas Rusia sebagai negara kuat dan besar di sistem internasional, dan hal tersebut penting karena pasca Perang Dingin kredibilitas Rusia sebagai negara besar terus dipertanyakan (Pakhomov, 2015). Rusia secara militer, memberikan bantuan langsung dengan kekuatan udaranya, memberikan dukungan bagi pasukan pemerintah di darat (Valenta \& Valenta, 2016).

Aktor Internasional lainnya yang juga memiliki kepentingan dan pengaruh strategis dalam konflik di Suriah adalah Amerika Serikat dan aliansinya. Kemungkinan perubahan politik di Suriah akan memberikan keuntungan strategis dan geopolitik bagi AS di kawasan Timur Tengah, melihat bagaimana pemerintahan Suriah selama ini merupakan sekutu Rusia di Timur Tengah. Selain itu, intervensi nyata Rusia di dalam konflik Suriah, menjadi tantangan bagi AS yang selama ini pasca Perang Dingin merupakan kekuatan utama yang dapat menyediakan keamanan melalui kemampuan militernya menggelar kekuatan di berbagai wilayah di dunia (Issa, 2016). Suriah juga menjadi kesempatan bagi AS untuk dapat menahan pengaruh dan kekuatan dari Iran dan menggangu rantai politik antara Hizbullah-Suriah-Iran (Cafiero \& Wagner, 2015). Presiden Barack Obama memberikan otoritas kepada pentagon untuk memberikan bantuan persenjataan kepada pihak oposisi yang melawan pemerintahaan Assad (Cassidy, 2015). Upaya AS dalam konflik di Suriah berfokus pada pemberian bantuan persenjataan bagi pemberontak, meskipun AS juga sempat mengupayakan memberikan pelatihan militer kepada kelompok pemberontak (Stewart \& Holton, 2015). 
Berdasarkan pada argumen Cunningham yang menyatakan bahwa, aktor negara eksternal memiliki resiko kerugian yang kecil di dalam keterlibatannya pada perang sipil. Hal tersebut akan mendorong negara untuk terus mengedepankan kepentingannya di dalam konflik karena mereka tidak secara langsung terkena dampak kehancuran dari perang tersebut. Oleh karena itu, perang sipil di Suriah akan terus berpotensi mengalami peningkatan eskalasi dan juga menjadi konflik yang berkepanjangan.

\section{Aktor Transnasional: Keterlibatan Kelompok Jihadis}

Pada kenyataannya, perang sipil di Suriah tidak hanya merupakan konflik antara penguasa dan oposisinya saja. Kelompok ekstrimis Islam atau juga sering disebut sebagai kelompok salafi jihadis, menjadi kelompok ketiga yang ikut berperan membentuk karakter konflik di Suriah. Meskipun memiliki kesamaan tujuan dengan kelompok oposisi; yaitu menjatuhkan pemerintahan Bashar al Assad, kelompok salafi jihadis ini memiliki visi dan ideologi politik yang jauh berbeda dengan kelompok oposisi. Hal tersebut membuat kemungkian akan munculnya aktor global non-negara yang memiliki kepentingan dan pengaruh penting di dalam konflik Suriah, diantaranya adalah Al Qaeda.

Meskipun berbagai media secara berlebihan menyatakan bahwa Al Qaeda memiliki peran di dalam konflik Suriah, masih belum terlalu jelas apakah Al Qaeda memang terlibat dan memiliki pengaruh langsung di dalam konflik Suriah. Namun, hal yang dapat dipastikan adalah bahwa kelompok-kelompok yang memiliki afiliasi dengan mereka di Suriah, ikut terlibat di dalam konflik ini. Kelompok-kelompok tersebut menurut Elizabeth O'bagy adalah Brigade Abdullah Azzam, beberapa elemen dari Al Qaeda Irak, Fatah al Sham, dan kelompok-kelompok salafi jihadis dari Jordania (O'bagy, 2012).

Selain itu, Al Qaeda juga mengirimkan beberapa pemimpin-pemimpin seniornya dan ahli-ahli strategi, untuk mengawasi pembentukan pasukan pelopor di tengah gerakan revolusi Suriah, setelah dimulainya perang sipil pada 2011. Beberapa orang yang dikirim tersebut; yang sering disebut sebagai kelompok khorasan oleh AS; tidak hanya memberikan pertimbangan dan saran bagi kelompok jihad seperti Jabhat al Nusra, tetapi juga kelompok-kelompok pemberontak yang lainnya. Al Qaeda berusaha untuk menumbuhkan rasa simpati dan dukungan pada tujuantujuannya dari kelompok-kelompok pemberontak (Cafarella, Heras, \& Casagrande, 2016).

Jabhat al Nusra muncul sebagai kelompok salafi jihadis yang paling menonjol dan memiliki pengaruh paling besar di antara berbagai kelompok pemberontak. Peningkatan kekuatan dan pengaruh kelompok ini di dalam konflik Suriah membuat karakter perang sipil di 
Suriah menjadi semakin rumit. Kelompok ini memiliki keterkaitan yang penting bagi Al Qaeda dan menunjukkan tingkat efektifitas yang lebih tinggi dibandingkan kelompok-kelompok pemberontak yang lainnya (O'bagy, 2012, p. 31). Kelompok ini juga menunjukkan kemampuannya dalam menarik dukungan masyarakat dan kelompok bersenjata dari beberapa wilayah populasi Suriah. Kelompok ini bisa menjadi kelompok yang lebih efektif dibandingkan kelompok-kelompok perlawanan seperti Free Syrian Army yang di dukung oleh aktor-aktor negara di kawasan regional dan internasional. Al Qaeda, melalui pernyataan pemimpinnya saat ini; Ayman al Zawahiri; merupakan pihak eksternal penting yang sampai saat ini secara jelas menyatakan dukungannya terhadap kelompok ini (Lister, 2015).

Keterlibatan dari kelompok jihadis ini memberi dimensi baru dalam kepentingan politik yang berbenturan dalam perang sipil di Suriah. Sehingga, keharian Jihadis telah mempengaruhi konflik yang ada dengan kemunculan variasi kepentingan yang berbeda dengan aktor eksternal lainnya. Tidak hanya kepentingan politik pemberontak untuk menggulingkan pemerintahan yang berkuasa, atau kepentingan politik rezim Assad untuk mempertahankan kekuasaannya saja; tetapi juga kepentingan kelompok jihadis untuk kekuasaannya di Suriah berdasarkan visi politik pribadi mereka. Hal ini tentu saja semakin menambah isu di dalam konflik yang terjadi. Isu sektarian akan muncul dan mengemuka di dalam perang sipil ini. Penambahan isu akan menghasilkan kesulitan dalam memformulasi persetujuan dan kesepahaman diantara pihak yang bertikai.

\section{KESIMPULAN}

Dari berbagai penjelasan pada bagian-bagian sebelumnya, maka dapat disimpulkan di dalam tulisan ini bahwa keterlibatan aktor-aktor eksternal di dalam perang sipil akan cenderung memperpanjang durasi konfliknya. Keterlibatan aktor-aktor eksternal menjadi penyebab dari berkepanjangannya konflik di Suriah. Hal ini tidak lain karena keterlibatan aktor eksternal menimbulkan penambahan kombatan di dalam konflik, sehingga preferensi di dalam konflik tersebut pun semakin bertambah. Semakin banyaknya preferensi yang berbeda-beda diantara pihak yang bertikai, akan menimbulkan kesulitan untuk menemukan titik temu dari suatu konflik untuk dapat di negosiasikan. Semakin suatu konflik domestik ter-fraksionalisasi, semakin sulit pula bagi pihak-pihak yang bertikai untuk melakukan kalkulasi atas hasil akhir dari konflik demi pemenuhan kepentingannya. Aktor eksternal juga pada akhirnya lebih mengutamakan kepentingan pribadinya dibandingkan kepentingan kubu-kubu domestik yang bertikai. Hal 
tersebut semakin menambahkan isu di dalam konflik tersebut dan penambahan isu akan semakin menyulitkan upaya-upaya persetujuan di dalam negosiasi.

Terdapat beberapa kondisi yang dapat menjadi faktor pendukung upaya resolusi konflik di Suriah. Melihat realita dari konflik yang terjadi di Suriah dan kesimpulan dari tulisan ini, dapat dikatakan bahwa semakin terlibatnya aktor-aktor eksternal justru akan mempersulit upaya penyelesaian konflik. Oleh karena itu, penyelesaian konflik akan semakin mudah dicapai apabila terdapat aktor-aktor eksternal yang mundur dari persaingan politik di Suriah; baik itu karena pertimbangan kemanusiaan ataupun pertimbangan rasional dimana kemungkinan untuk mendapatkan keuntungan dari konflik ini sudah semakin kecil atau bahkan tidak ada lagi. Upaya-upaya negosiasi perdamaian yang dilakukan sebelum terjadinya kondisi tersebut akan memiliki kemungkinan yang sangat kecil untuk berhasil memberikan dampak yang signifikan dalam menyelesaikan konflik berkepanjangan di Suriah ini.

\section{DAFTAR PUSTAKA}

Aljazeera. (2015, August 18). Almost quarter of a million people' dead in Syria war. Retrieved March 18, 2017, from https://www.aljazeera.com/news/2015/08/quarter-million-peopledead-syria-war-150807093941704.html

Alsharif, A. (2012, June 23). Saudi Arabia and Qatar funding Syrian rebels. Retrieved April 2, 2017, from https://www.reuters.com/article/us-syria-crisis-saudi/saudi-arabia-and-qatarfunding-syrian-rebels-idUSBRE85M07820120623

Amnesty International. (2016, February 3). Syria's refugee crisis in numbers. Retrieved April 4, 2017, from https://www.amnesty.org/en/latest/news/2016/02/syrias-refugee-crisis-innumbers/

Bagdonas, A. (2012). Interest in Syrian Conflict: Power, Prestige, and Profit Power, Prestige, and Proft. European Journal of Economic and Political Studies, 55-77.

Barfi, B. (2016, January 24). The Real Reason Why Iran Backs Syria. Retrieved April 2, 2017, from : https://nationalinterest.org/feature/the-real-reason-why-iran-backs-syria-14999

Barmin, Y. (n.d.). A Short History of Syria's Brutal First Family. Retrieved December 16, 2016, from https://mic.com/articles/62771/a-short-history-of-syria-s-brutal-firstfamily\#.TgA5p6x20

Basma, A., \& Strohecker, K. (2015, November 15). Saudi Arabia to continue support Syrian rebels if Assad does not leave. Retrieved 3 April, 2017, from https://www.reuters.com/article/us-mideast-crisis-syria-saudi/saudi-arabia-to-continuesupport-syrian-rebels-if-assad-does-not-leave-idUSKCN0T31A320151114

Bassam, L., \& Perry, T. (2015, November 7). Saudi Arabia's 'intensified' support to Syrian rebels is reportedly slowing regime advances. Retrieved April 3, 2017, from https://www.businessinsider.com/saudi-arabias-intensified-support-to-syrian-rebels-isreportedly-slowing-regime-advances-2015-11? IR=T

Cafarella, J., Heras, N. A., \& Casagrande, G. (2016, September 1). Al Qaeda Is Gaining Strength in Syria. Retrieved April 19, 2017, from https://foreignpolicy.com/2016/09/01/al-qaedais-gaining-strength-in-syria/ 
Cafiero, G., \& Wagner, D. (2015, November 8). U.S. and Iranian Interests in Syria. Retrieved April 8, 2017, from http://intpolicydigest.org/2015/11/08/u-s-and-iranian-interests-insyria/

Cassidy, J. (2015, November 3). America's Vital Interests in Syria. Retrieved April 8, 2017, from https://www.newyorker.com/news/john-cassidy/americas-vital-interests-in-syria

Collier, P., Hoeffler, A., \& Rohner, D. (2009). Beyond Greed and Grievance: Feasibility and Civil War. Oxford Economic Papers , 61 (1), 1-27.

Cunningham, D. E. (2010). Blocking resolution: How external states can prolong civil wars. Journal of Peace Research , 47 (2), 115-127.

Fulton, W., Holliday, J., \& Wyer, S. (2013, May). Iranian Strategy In Syria. Retrieved 2 April, 2017, from http://www.understandingwar.org/sites/default/files/IranianStrategyinSyria1MAY.pdf

Gleditsch, K. S. (2007). Transnational Dimensions of Civil War. Journal of Peace Research , 44 (3), 293-309.

Issa, A. (2016, October 13). Is War in Syria is America Interest? Retrieved April 7, 2017, from http://nationalinterest.org/feature/war-syria-americas-interest-18037?page=2

Lister, C. (2015, May 31). An internal struggle: Al Qaeda's Syrian affiliate is grappling with its identity. $\quad$ Retrieved April 22, 2017, from https://www.brookings.edu/blog/markaz/2015/05/31/an-internal-struggle-al-qaedassyrian-affiliate-is-grappling-with-its-identity/

Lister, C. (2016, November 26). The Free Syrian Army: A decentralized insurgent brand. Retrieved March 13, 2018, from https://www.brookings.edu/wpcontent/uploads/2016/11/iwr_20161123_free_syrian_army1.pdf

O'bagy, E. (2012). Jihad In Syria. Washington DC: Institute for the Study of War.

Pakhomov, N. (2015, November 18). What Does Russia Really Want in Syria? Retrieved April 5, 2017, from http://nationalinterest.org/feature/what-does-russia-really-want-syria14375 ?page $=2$

Rafizadeh, M. (n.d.). The Syrian Civil War: Four Concentric Forces of Tensions. Retrieved March 17, 2017, from https://scholarcommons.usf.edu/cgi/viewcontent.cgi?article=7008\&context=etd

Regan, P. M., \& Norton, D. (2005). Greed, Grievance, and Mobilization in Civil Wars. The Journal of Conflict Resolution , 49 (3), 319-336.

Rodgers, L., Gritten, D., Offer, J., \& Asare, P. (n.d.). Syria: The story of the conflict. Retrieved December 16, 2016, from https://www.bbc.com/news/world-middle-east-26116868

Stewart, P., \& Holton, K. (2015, October 9). U.S. pulls plug on Syria rebel training effort; will focus on weapons supply. Retrieved April 12, 2017, from https://www.reuters.com/article/us-mideast-crisis-syria-usa/u-s-pulls-plug-on-syria-rebeltraining-effort-will-focus-on-weapons-supply-idUSKCNOS31BR20151009

The Guardian. (n.d.). Like dictator, like son: how the Assads maintain a tight grip on power. Retrieved March 17, 2017, from https://www.theguardian.com/world/2012/mar/14/dictator-son-assad-grip-power

Valenta, J., \& Valenta, L. F. (2016). Why Putin Wants Syria. Middle East Quarterly, 23 (2). 